\title{
Vitamin D Serum Levels in Subjects Tested for SARS-CoV-2: What Are the Differences among Acute, Healed, and Negative COVID-19 Patients? A Multicenter Real-Practice Study
}

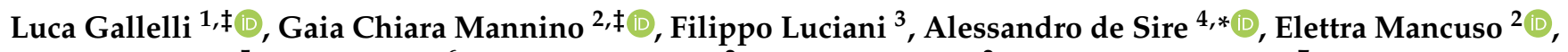 \\ Pietro Gangemi ${ }^{5}$, Lucio Cosco ${ }^{6}$, Giuseppe Monea ${ }^{2}$, Carolina Averta ${ }^{2}$, Pasquale Minchella ${ }^{7}$, Manuela Colosimo ${ }^{7}$, \\ Lucia Muraca ${ }^{8}$, Federico Longhini ${ }^{9}$, Antonio Ammendolia ${ }^{4}\left(\mathbb{0}\right.$, Francesco Andreozzi ${ }^{2}, *(\mathbb{D}$, \\ Giovambattista De Sarro ${ }^{1}$, G\&P Working Group ${ }^{\dagger}$ and Erika Cione ${ }^{10}$ (i)
}

check for updates

Citation: Gallelli, L.; Mannino, G.C.; Luciani, F.; de Sire, A.; Mancuso, E.; Gangemi, P.; Cosco, L.; Monea, G.; Averta, C.; Minchella, P.; et al. Vitamin D Serum Levels in Subjects Tested for SARS-CoV-2: What Are the Differences among Acute, Healed, and Negative COVID-19 Patients? A Multicenter Real-Practice Study. Nutrients 2021, 13, 3932. https:// doi.org/10.3390/nu13113932

Academic Editors: Igor Sergeev and Maria Luz Fernandez

Received: 7 October 2021

Accepted: 1 November 2021

Published: 3 November 2021

Publisher's Note: MDPI stays neutral with regard to jurisdictional claims in published maps and institutional affiliations.

Copyright: () 2021 by the authors. Licensee MDPI, Basel, Switzerland. This article is an open access article distributed under the terms and conditions of the Creative Commons Attribution (CC BY) license (https:// creativecommons.org/licenses/by/ $4.0 /)$.
1 Department of Health Science, School of Medicine, University of Catanzaro, Operative Unit of Clinical Pharmacology, Mater Domini University Hospital, 88100 Catanzaro, Italy; gallelli@unicz.it (L.G.); desarro@unicz.it (G.D.S.)

2 Department of Medical and Surgical Sciences, University Magna Graecia of Catanzaro, 88100 Catanzaro, Italy; gaiamannino@gmail.com (G.C.M.); elettramancuso@gmail.com (E.M.); giuseppe.monea93@gmail.com (G.M.); carolinaaverta90@gmail.com (C.A.)

3 Infectious Diseases Unit of Annunziata Hospital, 87100 Cosenza, Italy; filippoluciani@gmail.com

4 Physical Medicine and Rehabilitation Unit, Department of Medical and Surgical Sciences, University of Catanzaro "Magna Graecia", 88100 Catanzaro, Italy; ammendolia@unicz.it

5 Operative Unit of Clinical Chemistry Laboratory, Pugliese Ciaccio Hospital, 88100 Catanzaro, Italy; pgangemi@aocz.it

6 Department of Infectious Disease, Pugliese Ciaccio Hospital, 88100 Catanzaro, Italy; malattie.infettive@aocatanzaro.it

7 Department of Microbiology and Virology, Pugliese Ciaccio Hospital, 88100 Catanzaro, Italy; minchellap@tin.it (P.M.); manuelacolosimo@hotmail.it (M.C.)

8 Department of General Medicine, ASP 7, 88100 Catanzaro, Italy; luciamuraca@alice.it

9 Department of Anesthesiology and Reanimation, Pugliese Ciaccio Hospital, 88100 Catanzaro, Italy; flonghini@unicz.it

10 Department of Pharmacy, Health and Nutritional Sciences, Department of Excellence 2018-2022, University of Calabria, 87036 Cosenza, Italy; erika.cione@unical.it

* Correspondence: alessandro.desire@unicz.it (A.d.S.); andreozzi@unicz.it (F.A.); Tel.: +39-0961-7128-19 (A.d.S.); +39-0961-36471-20 (F.A.)

+ A complete list of the centers and investigators in the G\&P Working Group is provided in Appendix A.

$\ddagger \quad$ These authors contributed equally to this work.

Abstract: Vitamin D might play a role in counteracting COVID-19, albeit strong evidence is still lacking in the literature. The present multicenter real-practice study aimed to evaluate the differences of $25(\mathrm{OH}) \mathrm{D}_{3}$ serum levels in adults tested for SARS-CoV-2 (acute COVID-19 patients, subjects healed from COVID-19, and non-infected ones) recruited over a 6-month period (March-September 2021). In a sample of 117 subjects, a statistically significant difference was found, with acute COVID-19 patients demonstrating the lowest levels of serum $25(\mathrm{OH}) \mathrm{D}_{3}(9.63 \pm 8.70 \mathrm{ng} / \mathrm{mL})$, significantly lower than values reported by no-COVID-19 patients $(15.96 \pm 5.99 \mathrm{ng} / \mathrm{mL}, p=0.0091)$ and healed COVID-19 patients $(11.52 \pm 4.90 \mathrm{ng} / \mathrm{mL}, p>0.05)$. Male gender across the three groups displayed unfluctuating $25(\mathrm{OH}) \mathrm{D}_{3}$ levels, hinting at an inability to ensure adequate levels of the active vitamin D3 form $(1 \alpha, 25(\mathrm{OH}) 2 \mathrm{D} 3)$. As a secondary endpoint, we assessed the correlation between serum $25(\mathrm{OH}) \mathrm{D}_{3}$ levels and pro-inflammatory cytokine interleukin-6 (IL-6) in patients with extremely low serum $25(\mathrm{OH}) \mathrm{D}_{3}$ levels $(<1 \mathrm{ng} / \mathrm{mL})$ and in a subset supplemented with $1 \alpha, 25(\mathrm{OH})_{2} \mathrm{D}_{3}$. Although patients with severe hypovitaminosis-D showed no significant increase in IL-6 levels, acute COVID-19 patients manifested high circulating IL-6 at admission (females $=127.64 \pm 22.24 \mathrm{pg} / \mathrm{mL}$, males $=139.28 \pm 48.95 \mathrm{ng} / \mathrm{mL})$ which dropped drastically after the administration of $1 \alpha, 25(\mathrm{OH})_{2} \mathrm{D}_{3}$ $(1.84 \pm 0.77 \mathrm{pg} / \mathrm{mL}$ and $2.65 \pm 0.92 \mathrm{ng} / \mathrm{mL}$, respectively). Taken together, these findings suggest that an administration of $1 \alpha, 25(\mathrm{OH})_{2} \mathrm{D}_{3}$ might be helpful for treating male patients with an acute COVID-19 infection. Further studies on rapid correction of vitamin D deficiency with fast acting metabolites are warranted in COVID-19 patients. 


\section{Introduction}

The current pandemic infection of coronavirus disease 2019 (COVID-2019) is caused by severe acute respiratory syndrome coronavirus-2 (SARS-CoV-2), a novel RNA $\beta$-coronavirus that shares $79 \%$ sequence homology with SARS-CoV [1]. Even if to date there is no evidence that a specific therapy could improve the outcomes in patients with COVID-19, several pharmacological treatments, including vitamin D3, could negatively influence the infection progression acting on the immune system [1,2].

In fact, both immune dysfunction and cytokine storm are involved in the development of COVID-19 [3,4]; some authors have documented that vitamin D3 is able to improve the symptoms of SARS-CoV-2 infection because it acts on the immune system and modulates lung function [3], other authors have suggested that vitamin D3 supplementation may reduce the risk of SARS-CoV-2 infection $[4,5]$.

Vitamin D3 (in animals, including humans), is considered biologically inactive until it undergoes two enzymatic hydroxylation reactions. The first takes place in the liver and it is mediated by the 25-hydroxylase, most likely cytochrome P450 CYP2R1, which forms 25-hydroxyvitamin $\mathrm{D}\left[25(\mathrm{OH}) \mathrm{D}_{3}\right]$ (calcidiol, calcifediol) [6]. The second reaction takes place in the kidney and is mediated by the $1 \alpha$-hydroxylase (also known as cytochrome P450 CYP27B1), which converts $25(\mathrm{OH}) \mathrm{D}_{3}$ to the biologically active hormone, $1 \alpha, 25$-dihydroxy vitamin D3 $\left(1 \alpha, 25(\mathrm{OH})_{2} \mathrm{D}_{3}\right)$. The binding of $1 \alpha, 25(\mathrm{OH})_{2} \mathrm{D}_{3}$ to the vitamin $\mathrm{D}$ receptor (VDR) induces the formation of a coactivator complex leading to target gene transactivation [7]. The VDR-RXR $\alpha$ coactivator complex can directly affect the genes to which VDR was previously attached, or it can reallocate and promote the transcription of other genomic sites, therefore leaving regulatory sequences uncovered for positive gene regulation by other transcription factors. This mechanism ensures the extra-skeletal effects of vitamin D3 on endothelial modulation, muscle mass and function, metabolic control, and the immune system, including cytokine expression profile [7-11].

Data from the UK-Biobank showed that although circulating vitamin D levels did not affect the risk of COVID-19 infection, the habitual use of vitamin D supplements was significantly associated with a $34 \%$ lower risk of COVID-19 infection $(p=0.034)$ [12]. Notably, vitamin D plays a physiologic role in regulating normal innate and adaptive immunity [13], and it has been reportedly shown to be able to suppress pro-inflammatory and stimulate anti-inflammatory cytokine formation, which might have a positive impact on COVID-19 patients $[13,14]$. In this scenario, COVID-19 pandemic has placed under the spotlight the correlation among IL-6, cytokine release syndrome, hyperinflammation state and COVID-19 fatality rate $[15,16]$.

Our hypothesis is that there might be a strict correlation between vitamin D status and IL-6 serum levels. Nonetheless, albeit a role of vitamin D has been proposed in counteracting COVID-19 $[3,4,13,14]$ through the potential modulation of the immune dysfunction and cytokine storm, to date, there is still a lack of evidence in the literature in terms of differences in serum levels across large cohorts, according to disease status.

Therefore, by the present study, we aimed to evaluate the levels of serum $25(\mathrm{OH}) \mathrm{D}_{3}$ in subjects tested for SARS-CoV-2 (acute COVID-19 patients, subjects healed from COVID-19, and non-infected ones). Furthermore, we sought to evaluate the effects of the supplementation of $1 \alpha, 25(\mathrm{OH})_{2} \mathrm{D}_{3}$ on IL- 6 and $25(\mathrm{OH}) \mathrm{D}_{3}$ serum levels in a sub-group of COVID-19 patients with chronic renal failure and hypovitaminosis $\mathrm{D}$.

\section{Materials and Methods}

\subsection{Data Collection}

In this multicenter real practice study, we recruited patients with symptoms of an acute airway disease (e.g., cough, sore throat, breathing difficulties) referred to the Emergency 
Department of "Pugliese Ciaccio" Hospital, or to the Intensive Care Unit of the University Hospital "Azienda Policlinico Mater Domini", both located in Catanzaro, Italy, over a 6-month period (from 30 March 2021 to 30 September 2021). All study participants underwent a naso-pharyngeal swab real-time reverse transcription polymerase chain reaction (RT-PCR) analysis for SARS-CoV-2. This study is part of the clinical trials recorded in clinicaltrial.gov (NCT04322513) and was conducted in compliance with the Institutional Review Board/Human Subjects Research Committee requirements. All participants, or their legal guardians, were asked to carefully read and sign an informed consent, and researchers provided to protect the privacy and the study procedures according to the Declaration of Helsinki and the Guidelines for Good Clinical Practice criteria, with pertinent National and International regulatory requirements. Data collection and reporting were performed in accordance with the Strengthening the Reporting of Observational studies in Epidemiology (STROBE) guidelines. The study was approved by the Institutional Ethics Committee (approval code: 2020.68).

\subsection{Study Participants}

Eligible patients were of both sexes, aged $>18$ years, with symptoms of an acute airway disease (e.g., cough, sore throat, breathing difficulties), with or without fever, muscle pain, or sudden anosmia or ageusia. A diagnosis of SARS-CoV-2 infection was postulated based on RT-PCR analysis of naso-pharyngeal swabs. The presence of anti-SARS-CoV-2 IgG was investigated to establish the existence of previous contacts with the virus. Patients who did not sign the informed consent or had been taking medicinal preparations and dietary supplements with vitamin D or cod-liver oil within the previous three months were not considered eligible for the study.

\subsection{Experimental Protocol}

After clinical, biochemical, microbiological, and radiological evaluation, patients were included and divided into four groups:

Group 1: SARS-CoV-2 acute infection with a positivity to naso-pharyngeal swab RT-PCR analysis (COVID-19);

Group 2: patients negative for both naso-pharyngeal swab RT-PCR and IgG anti SARS-CoV-2 analysis (no-COVID-19);

Group 3: patients healed from SARS-CoV-2 infection; with negative naso-pharyngeal swab RT-PCR analysis and positive to IgG anti SARS-CoV-2 (h-COVID-19);

Group 4: SARS-CoV-2 acute infection with a positivity to naso-pharyngeal swab RT-PCR analysis, and with hypovitaminosis D, who underwent 1-week treatment with $0.25 \mu \mathrm{g}$ of $1 \alpha, 25(\mathrm{OH}) 2 \mathrm{D}_{3}$ per day, at 1 week from the admission (vd-COVID-19).

\subsection{Endpoints}

The first endpoint was to determine a statistically significant difference in terms of serum 25(OH) $\mathrm{D}_{3}$ levels among SARS-CoV-2 healed patients (Group 3; h-COVID-19), SARSCoV-2 infected patients (Group 1; COVID-19) and patients never infected by SARS-CoV-2 (Group 2; no-COVID-19). Moreover, the effects of $1 \alpha, 25(\mathrm{OH})_{2} \mathrm{D}_{3}$ in COVID-19 infected patients (Group 4; vd-COVID-19) was evaluated.

The second endpoint was the correlation between serum $25(\mathrm{OH}) \mathrm{D}_{3}$ and IL-6 levels, in patients with extremely low serum $25(\mathrm{OH}) \mathrm{D}_{3}$ levels $(<1 \mathrm{ng} / \mathrm{mL})$.

Lastly, in all four groups, we also evaluated the gender-related statistically significant difference in serum $25(\mathrm{OH}) \mathrm{D}_{3}$ levels.

\subsection{Reverse Transcription Polymerase Chain Reaction (RT-PCR) Assay for SARS-CoV-2}

Naso-pharyngeal swab samples were collected for extracting SARS-CoV-2 RNA from patients suspected of having COVID-19. All test swabs were placed in a collection tube with $150 \mu \mathrm{L}$ of virus preservation solution, and total RNA was extracted within $2 \mathrm{~h}$ using automated nucleic acids extraction and PCR setup (Nimbus, Seegene, Seoul, Korea). 
The suspension was used for RT-PCR assay of SARS-CoV-2 RNA. Two target genes for SARS-CoV-2, including RNA-dependent RNA polymerase and nucleo-capsid protein, were simultaneously amplified and tested during the RT-PCR assay. The RT-PCR assay was performed using a SARS-CoV-2 nucleic acid detection kit according to the manufacturer's protocol (Allplex ${ }^{\mathrm{TM}}$ 2019-nCoV Assay-Seegene, Seoul, Korea). RT-PCR assay was performed under the following conditions: incubation at $50{ }^{\circ} \mathrm{C}$ for $15 \mathrm{~min}$ and $95{ }^{\circ} \mathrm{C}$ for $5 \mathrm{~min}$, 45 cycles of denaturation at $94^{\circ} \mathrm{C}$ for $15 \mathrm{~s}$, and extending and collecting fluorescence signal at $55^{\circ} \mathrm{C}$ for $45 \mathrm{~s}$. A cycle threshold value (Ct-value) of less than 39 was defined as a positive test result, and a Ct-value of 40 or more was defined as a negative test. These diagnostic criteria were based on the recommendation by the Italian Health Institute according to World Health Organization (WHO) Berlin recommendation.

\subsection{Serum $25(\mathrm{OH}) \mathrm{D}_{3}$ and Interleukin-6 (IL-6) Detection}

Blood samples were collected from all the patients in the different groups at the time of hospitalization and then centrifuged. Serum aliquots were prepared and stored at $-20{ }^{\circ} \mathrm{C}$ in screened and standard tubes for further analysis.

Serum samples were processed using chemiluminescent immunoassay technique through the Architect I1000 ${ }^{\circledR}$ (Abbott Diagnostics, Lake Forest, IL, USA; LOD $2.2 \mathrm{ng} / \mathrm{mL}$ ), using an internal quality control system to ensure the assay validity. Each detection for $25(\mathrm{OH}) \mathrm{D}_{3}$ and IL-6 was performed in triplicate to reduce the technical error.

\subsection{Statistical Analysis}

Continuous data are expressed as mean \pm standard deviation (SD) and categorical data as counts and percentages. A one-way ANOVA test was used to evaluate the differences within the groups. Differences identified by ANOVA were examined by using a KruskalWallis test followed by Dunn's multiple comparison test. The Pearson test was used to evaluate the correlation between serum $25(\mathrm{OH}) \mathrm{D}_{3}$ levels and IL-6 levels. Wilcoxon matched-paired singed rank test was employed to analyze the difference in $25(\mathrm{OH}) \mathrm{D}_{3}$ and IL-6 levels before and after treatment with $1 \alpha, 25(\mathrm{OH})_{2} \mathrm{D}_{3}$ supplementation. GraphPad 5.0 software was used for the statistical analyses (GraphPad Software, San Diego, CA, USA).

\section{Results}

We recruited 133 patients of both sexes, and after clinical and laboratory evaluation, 16 were excluded (12.0\%), eight because their legal guardians did not sign the informed consent, and eight because they used vitamin D supplementation before the beginning of the study. The remaining 117 patients (87.9\%) were included and assigned to the 4 study groups:

Group 1: COVID-19, $n=40$ (30.1\%): 27 males (67.5\%) and 13 females (32.5\%), with an age at diagnosis ranging from 38 to 83 years (mean $56.0 \pm 7.7$ years for males; $57.6 \pm 13.7$ years for females);

Group 2: no-COVID-19, $n=38$ (28.5\%): 23 males (60.5\%) and 15 females (39.5\%), with average age ranging from 25 to 72 years (mean $53.2 \pm 9.5$ years for males; $44.3 \pm 13.2$ years for females);

Group 3: h-COVID-19, $n=27$ (20.3\%): 19 males (70.4\%) and 8 females (29.6\%), with an age at diagnosis ranging from 21 to 63 years (mean $56.0 \pm 7.7$ years for males; $57.6 \pm 13.7$ years for females).

Group 4: vd-COVID-19, $n=12(9.0 \%)$ : 7 males (58.3\%) and 5 females $(41.6 \%)$, with an age at diagnosis ranging from 76 to 82 years (mean: $79 \pm 2.2$ years for males; $74.8 \pm 2.9$ years for females) with chronic renal failure, who underwent 1-week treatment with $1 \alpha, 25(\mathrm{OH})_{2} \mathrm{D}_{3}, 0.25 \mu \mathrm{g}$ per day.

Using the chemiluminescent immunoassay (CLIA) technique, we were able to identify subjects with insufficient serum $25(\mathrm{OH}) \mathrm{D}_{3}$ levels in respect to the actual range considered normal $(>30 \mathrm{ng} / \mathrm{mL})$. 
As per our primary endpoint, we evaluated the existence of a statistical difference in $25(\mathrm{OH}) \mathrm{D}_{3}$ serum levels among the three study groups. We documented that serum levels of $25(\mathrm{OH}) \mathrm{D}_{3}$ in COVID-19 patients $(9.63 \pm 8.70 \mathrm{ng} / \mathrm{mL})$ were significantly lower $(p=0.0091)$ than values reported by no-COVID-19 patients $(15.96 \pm 5.99 \mathrm{ng} / \mathrm{mL})$. Notably, we reported the absence of a significant difference $(p>0.05)$ between COVID-19 and h-COVID-19 patients (11.52 $\pm 4.90 \mathrm{ng} / \mathrm{mL})$, albeit even in this case the COVID-19 group showed lower levels of serum $25(\mathrm{OH}) \mathrm{D}_{3}$ (see Figure 1 for further details).

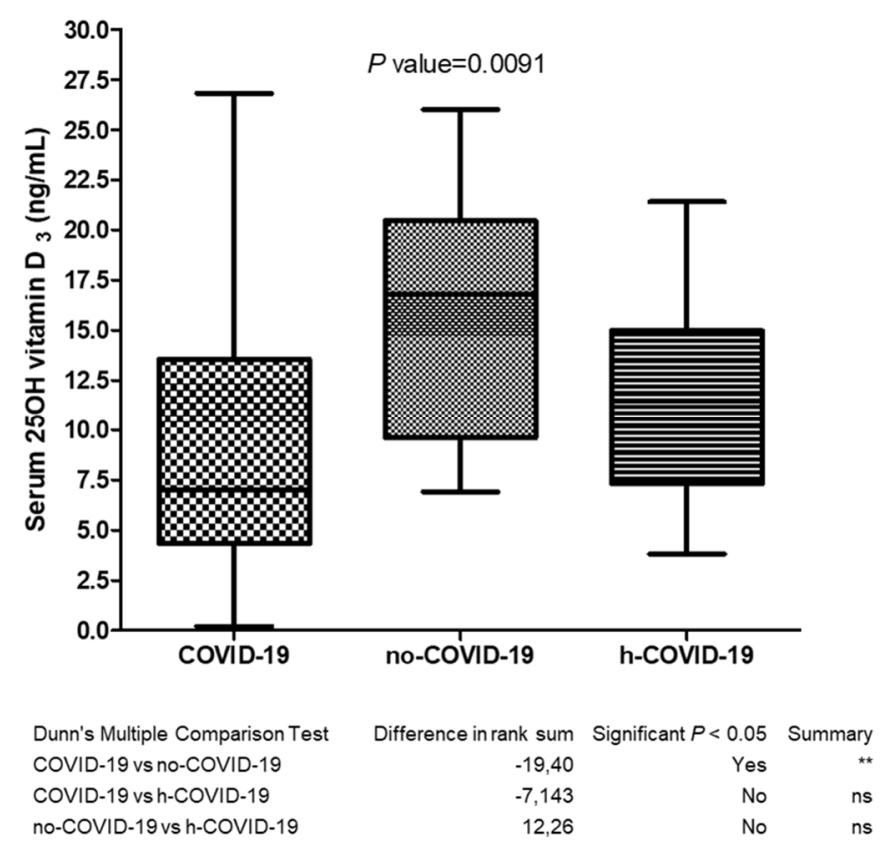

Figure 1. Serum 25(OH) vitamin D3 determination in COVID-19 (Group 1), no-COVID-19 (Group 2) and h-COVID (Group 3); ns = not significant, ${ }^{* *} p$ value $=0.0091$.

When we stratified the data by gender, we observed no difference in the male population, with a range of $25(\mathrm{OH}) \mathrm{D}_{3}$ serum levels of $10.4 \pm 7.3 \mathrm{ng} / \mathrm{mL}$ in COVID-19 patients; $11.8 \pm 4.3 \mathrm{ng} / \mathrm{mL}$ in no-COVID-19; and $11.7 \pm 5.3 \mathrm{ng} / \mathrm{mL}$ in h-COVID-19 (Figure 2A).

On the other hand, we documented a significant difference in serum $25(\mathrm{OH}) \mathrm{D}_{3}$ levels in COVID-19 female patients (11.7 $\pm 9.5 \mathrm{ng} / \mathrm{mL})$ in respect to no-COVID-19 group $(17.7 \pm 4.7 \mathrm{ng} / \mathrm{mL})$ with a $p=0.006$ (Figure $2 \mathrm{~B}$ ). The female no-COVID-19 group showed $25(\mathrm{OH}) \mathrm{D}_{3}$ levels significantly higher than the female h-COVID-19 $(9.2 \pm 2.8 \mathrm{ng} / \mathrm{mL})$ group, with a $p$-value $=0.019$ (Figure 2B). No significant differences emerged when we compared COVID-19 (11.7 $\pm 9.5 \mathrm{ng} / \mathrm{mL})$ and h-COVID-19 $(9.2 \pm 2.8 \mathrm{ng} / \mathrm{mL})$ female patients.

Overall, six patients belonging to Group 2 (COVID-19, four females and two males) showed extremely low serum $25(\mathrm{OH}) \mathrm{D}_{3}$ levels $(<1 \mathrm{ng} / \mathrm{mL})$. As per our secondary endpoint, we assessed circulating IL-6 levels in this subgroup of patients with extreme hypovitaminosis D (see Table 1 for further details). 
A

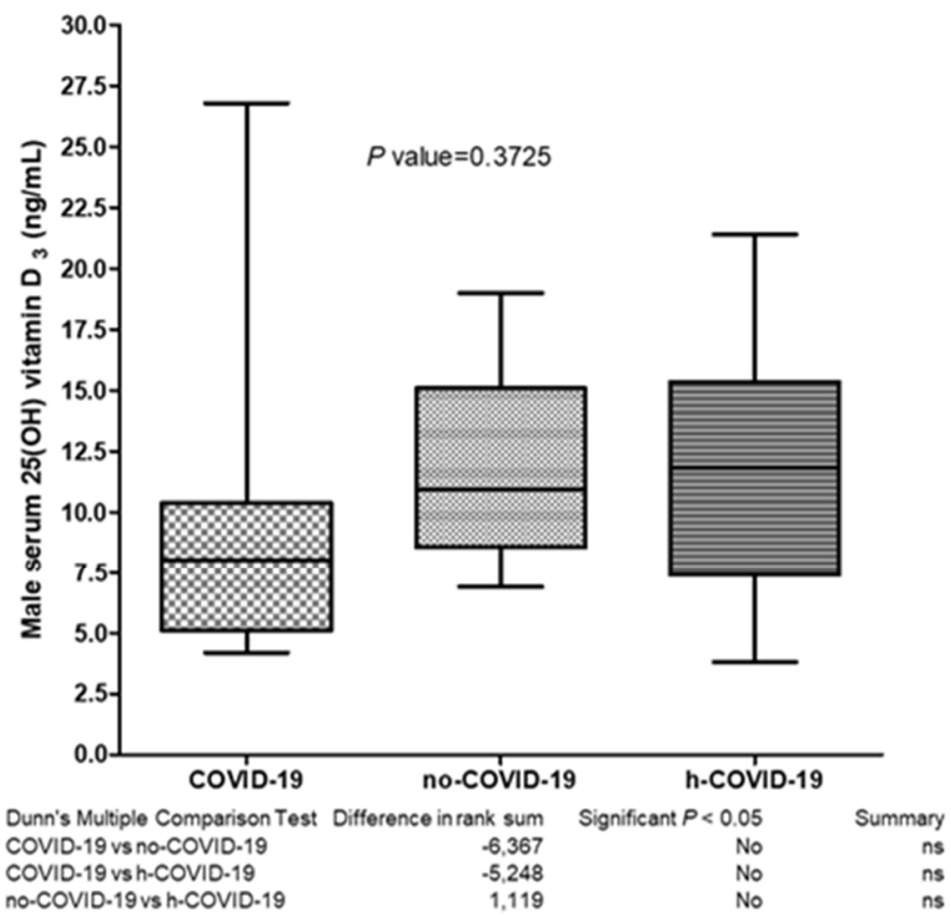

B

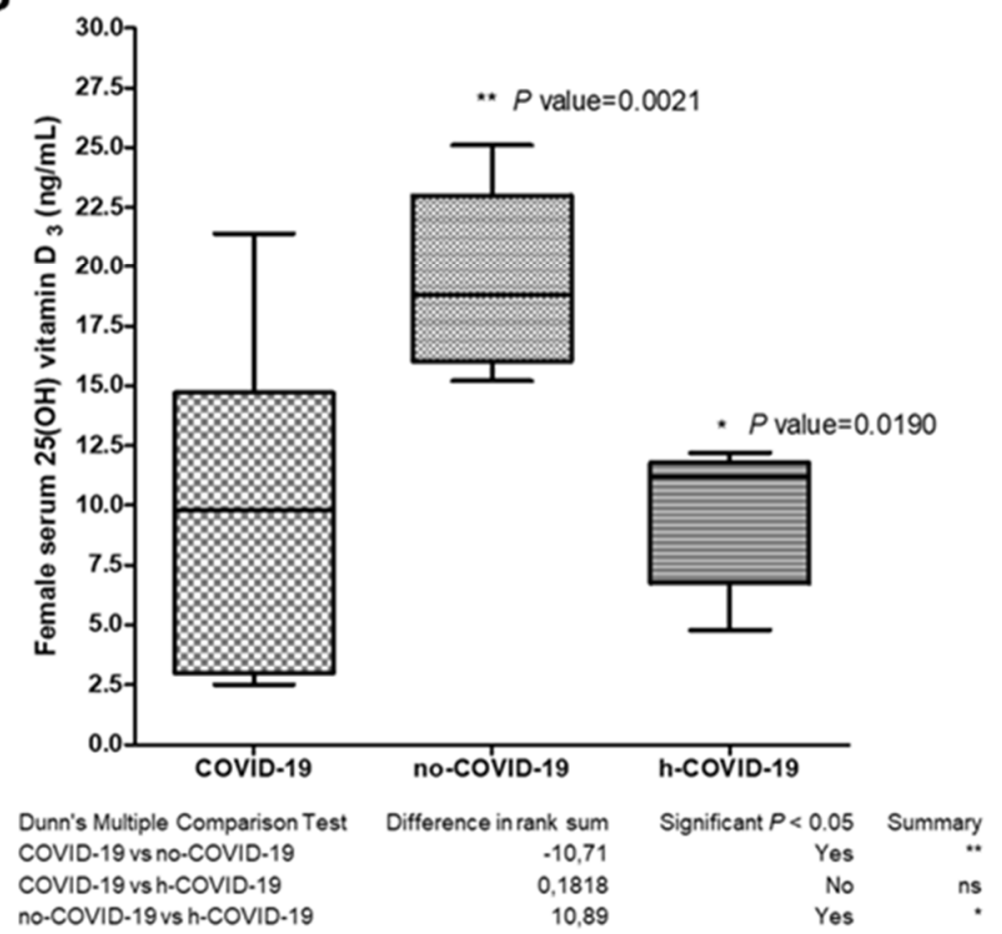

Figure 2. Serum 25(OH) vitamin D3 levels in COVID-19 (Group 1), no-COVID-19 (Group 2) and h-COVID (Group 3), dived per sex in (A) male and (B) female. $n s=$ not significant. ${ }^{*} p$ value $=0.0190$, ** $p$ value $=0.0021$. 
Table 1. Serum levels of 25(OH) $\mathrm{D}_{3}$ and IL-6 determination in COVID-19 patients with extremely low $25(\mathrm{OH}) \mathrm{D}_{3}$ serum levels $(n=6)$.

\begin{tabular}{cccc}
\hline Sex & $\begin{array}{c}\text { Age } \\
\text { (years) }\end{array}$ & $\begin{array}{c}\mathbf{2 5}(\mathbf{O H}) \mathbf{D}_{3} \\
(\mathbf{n g} / \mathbf{m L})\end{array}$ & $\begin{array}{c}\text { IL-6 } \\
(\mathbf{p g} / \mathbf{m L})\end{array}$ \\
\hline Female & 62 & 0.35 & 2.1 \\
Female & 63 & 0.25 & 2.6 \\
Female & 57 & 0.30 & 2.5 \\
Female & 60 & 0.72 & 2.8 \\
Male & 74 & 0.84 & 4.7 \\
Male & 69 & 0.90 & 4.3 \\
\hline
\end{tabular}

Surprisingly, none of these patients exceeded circulating levels of IL-6, and they all stayed within the range of normality, with mean $=3.16 \pm 1.2 \mathrm{pg} / \mathrm{mL}$. Considering the small sample size $(n=6)$, we performed an exploratory non-parametric correlation analysis, which showed a positive correlation between $25(\mathrm{OH}) \mathrm{D}_{3}$ and IL-6 levels (Spearman correlation coefficient $=0.759, p=0.04$ ).

Besides that, the 12 patients in Group 4 (vd-COVID-19, 5 females and 7 males) showed low serum $25(\mathrm{OH}) \mathrm{D}_{3}$ levels (mean $=13.6 \pm 1.1 \mathrm{ng} / \mathrm{mL}$ for females and $15 \pm 3.5 \mathrm{ng} / \mathrm{mL}$ for males) at admission, with no difference by gender, consistent with the results obtained in Group 1. All of them were alive after 2 weeks from admission. As reported in Table 2 both the circulating levels of $25(\mathrm{OH}) \mathrm{D}_{3}$ and IL-6 significantly decreased after the administration of $1 \alpha, 25(\mathrm{OH})_{2} \mathrm{D}_{3}$. IL-6 serum levels were high at admission in both females $(127.64 \pm 22.24 \mathrm{pg} / \mathrm{mL})$ and males $(139.28 \pm 48.95 \mathrm{ng} / \mathrm{mL})$, and dropped drastically after 1-week of supplementation with $1 \alpha, 25(\mathrm{OH})_{2} \mathrm{D}_{3}$, showing mean IL-6 $=1.84 \pm 0.77 \mathrm{pg} / \mathrm{mL}$ in females and $2.65 \pm 0.92 \mathrm{ng} / \mathrm{mL}$ in males.

Table 2. Serum levels of $25(\mathrm{OH}) \mathrm{D}_{3}$ (normal values $>30 \mathrm{ng} / \mathrm{mL}$ ) and IL-6 (normal values $<6 \mathrm{pg} / \mathrm{mL}$ ) determination after $1 \alpha, 25(\mathrm{OH})_{2} \mathrm{D}_{3}$ administration in vd-COVID-19 patients $(n=12)$.

\begin{tabular}{|c|c|c|c|c|c|c|c|}
\hline \multirow{2}{*}{ Sex } & \multirow{2}{*}{$\begin{array}{c}\text { Age } \\
\text { (Years) }\end{array}$} & \multicolumn{3}{|c|}{$25(\mathrm{OH}) \mathrm{D}_{3}(\mathrm{ng} / \mathrm{mL})$} & \multicolumn{3}{|c|}{ IL-6 (pg/mL) } \\
\hline & & Admission After & 2 Weeks & $p$-Value & Admission & After 2 Weeks & $p$-Value \\
\hline F & 73 & 15 & 13 & & 132.1 & 2 & \\
\hline $\mathrm{F}$ & 74 & 14 & 12 & & 151.8 & 1.5 & \\
\hline $\mathrm{F}$ & 73 & 13 & 11 & & 111 & 1.8 & \\
\hline $\mathrm{F}$ & 80 & 12 & 11 & & 99 & 0.9 & \\
\hline $\mathrm{F}$ & 74 & 14 & 13 & & 144.3 & 3 & \\
\hline $\mathrm{M}$ & 76 & 19 & 18 & 0.025 & 141 & 2 & 0.0022 \\
\hline $\mathrm{M}$ & 82 & 12 & 11 & & 200 & 3.5 & \\
\hline $\mathrm{M}$ & 80 & 12 & 12 & & 89 & 4.2 & \\
\hline $\mathrm{M}$ & 81 & 13 & 13 & & 65 & 3 & \\
\hline $\mathrm{M}$ & 78 & 12 & 11 & & 185 & 2.1 & \\
\hline $\mathrm{M}$ & 77 & 18 & 17 & & 162 & 2 & \\
\hline $\mathrm{M}$ & 79 & 19 & 18 & & 133 & 1.8 & \\
\hline
\end{tabular}

\section{Discussion}

In the present real-life study, we have evaluated the levels of serum $25(\mathrm{OH}) \mathrm{D}_{3}$ in recovered COVID-19 (h-COVID-19) patients, compared to acute infected (COVID-19) and non-infected ones (no-COVID-19).

Vitamin D acts as a lipophilic hormone and can be obtained from both nutritional intervention and sunlight exposure. Besides maintaining bone homeostasis, vitamin $\mathrm{D}$ is involved in the mechanisms of immune response [17]. Indeed, the scientific literature has recently pointed out the interaction between vitamin D and the immune system, suggesting that the former may play a key role in regulating normal innate and adaptive immunity [13]. In addition to this, previous studies have demonstrated an association between vitamin D deficiency and infectious processes [18-20]. Lu et al. [21], suggested 
that insufficient $25(\mathrm{OH}) \mathrm{D}_{3}$ levels are associated with an increase of both inflammatory cytokines and respiratory infections.

Notably, a retrospective study reported an association between low serum $25(\mathrm{OH}) \mathrm{D}_{3}$ levels and SARS-CoV-2 infection [22] and, more recently, other authors documented that insufficient serum $25(\mathrm{OH}) \mathrm{D}_{3}$ levels could represent a risk factor for the development of SARS-CoV-2 infection [5]. Accordingly, in this study, we documented the prevalence of $25(\mathrm{OH}) \mathrm{D}_{3}$ insufficiency $(<30 \mathrm{ng} / \mathrm{mL})$ in SARS-CoV-2 acute and healed infection as well as in Group 2, which encompassed patients without COVID-19 who had been admitted to the intensive care unit with symptoms of an acute airway disease. Of note, an insufficient level of $25(\mathrm{OH}) \mathrm{D}_{3}$ has been reported for several other conditions (e.g., COPD, obesity, diabetes, migraine, infections, cancer) [23-29]. Moreover, D'Avolio et al. [22] in 1377 control patients reported values of serum $25(\mathrm{OH}) \mathrm{D}_{3}$ levels lower than $30 \mathrm{ng} / \mathrm{mL}$ in patients with high levels of $C$ reactive protein. In this concern, we found significantly higher serum $25(\mathrm{OH}) \mathrm{D}_{3}$ levels in no-COVID-19 patients compared to COVID-19 ones, but no differences between the former group and h-COVID-19.

Sexual bias is a hallmark in various diseases including infectious conditions [30], therefore, we decided to stratify our patients by gender, considering that males usually get the worst prognosis for COVID-19 [31]. In the present study, we highlighted a significant increase in serum $25(\mathrm{OH}) \mathrm{D}_{3}$ levels in the female no-COVID-19 group with respect to COVID-19 and h-COVID-19 female cohorts, whereas no differences were detectable among the male cohorts. The immune inflammatory response triggered by bacteria and virus infection is critical for the disease outcome, and the host benefits from an acute reaction when it is kept under tight control, with balanced protective vs. excessive/pathological inflammation. An example of viral infection models, known to cause more severe heart muscle inflammation in males than in females, is the Coxsackievirus B3 [32]. Notably, estradiol promotes immune regulation that favors a protective response in females [33]. Gender difference in vitamin D status is also a crucial research topic [34].

It has been recently reported that vitamin $\mathrm{D}$ deficiency is associated with increased levels of IL-6 in patients with HIV infections [35,36]. In agreement with this, experimental studies in mice revealed that vitamin D levels are inversely linked to IL-6 liver expression [37]. Low levels of serum $25(\mathrm{OH}) \mathrm{D}_{3}$ levels increase IL-6 synthesis and vice versa. In this context, targeting the IL-6 pathway could be an innovative therapeutic approach for COVID19 patients, particularly in the elderly [15,38]. In our study, we noticed a subgroup of patients (four females and two males) characterized by extremely low levels of $25(\mathrm{OH}) \mathrm{D}_{3}$ $(<1 \mathrm{ng} / \mathrm{mL}$, tested twice for confirmation). Therefore, in this subpopulation we dosed circulating levels of IL-6 and, surprisingly, we found normal levels IL-6. Due to the small sample size, we cannot exclude the presence of confounding factors, such as a VDR mutation that could decreases the affinity of the receptor for its ligand and, therefore, increase the demand of $1 \alpha, 25(\mathrm{OH})_{2} \mathrm{D}_{3}$ from extra renal tissues that increased $1 \alpha$-hydroxylase expression in an inflammatory milieu [31]. On the other hand, it could be argued that in a scenario of chronic renal failure $25(\mathrm{OH}) \mathrm{D}_{3}$ is not efficiently converted to the active form $1 \alpha, 25(\mathrm{OH})_{2} \mathrm{D}_{3}$, and patients have been reported displaying normal values of $25(\mathrm{OH}) \mathrm{D}_{3}$ levels $(26 \mathrm{ng} / \mathrm{mL})$ and hugely increased IL-6 concentrations $(580 \mathrm{pg} / \mathrm{mL})$. Clearly, in the presence of chronic renal failure any compensation provided by extra-renal calcitriol synthesis is insufficient to ensure adequate levels of the active vitamin $\mathrm{D}$ form. Furthermore, it should be noted that low serum levels of $25(\mathrm{OH}) \mathrm{D}_{3}$ are frequent in severe COVID-19 patients that commonly present several functional impairments [12,39-42].

When we corrected the condition of hypovitaminosis $\mathrm{D}$ in a small group of COVID19 patients with chronic renal failure by supplementing $1 \alpha, 25(\mathrm{OH})_{2} \mathrm{D}_{3}$ for one week, we observed a steep and significant decrease in circulating IL-6 levels. Our findings suggest that rapidly acting vitamin D metabolites are more likely to be effective in treating such patients than cholecalciferol itself. The emerging literature [41,42] supports this concept and it should be investigated in more depth by further studies on larger samples. 
We are aware that the present study is not free from limitations: first, the small sample size that does not guarantee high external validity. Second, the absence of data on mutations of the VDR. Third, the fact that calcitriol is formed in many tissues including immune system cells, therefore its intracellular concentration may be higher than that found in the circulation, thus leading us to not assume that only those with chronic renal failure are short of calcitriol in their immune tissues.

However, this is the first study that: (i) evaluated patients in the real-life context, without exclusion for co-morbidities; (ii) investigated the levels of vitamin D in h-COVID-19; (iii) assessed the patients in a very short time and this excluded the possibility that sun exposition could modify $25(\mathrm{OH}) \mathrm{D}_{3}$ levels; (iv) performed a stratification by gender; (v) proved how calcitriol can be useful in COVID-19 patients with chronic renal failure.

\section{Conclusions}

Taken together, the findings of this multicenter cross-sectional study showed insufficient $25(\mathrm{OH}) \mathrm{D}_{3}$ serum levels in real-life patients with and without COVID-19, and in subjects healed from COVID-19. We collected evidences that males, who usually have a worst prognosis for COVID-19, display unfluctuating $25(\mathrm{OH}) \mathrm{D}_{3}$ levels that in turn could not ensure adequate levels of the active vitamin $\mathrm{D}$ form. Therefore, we could affirm that an administration of $1 \alpha, 25(\mathrm{OH})_{2} \mathrm{D}_{3}$, without neglecting the hypercalcemic risk, might be considered as an adequate indication for treating male COVID-19 patients.

Author Contributions: Conceptualization, L.G., F.L. (Federico Longhini), E.C.; methodology, P.G., M.C.; validation, A.d.S., M.C., F.A., E.M.; formal analysis, L.G., E.M., E.C., C.A. and G.C.M.; investigation, M.C., P.M., L.C., F.L. (Filippo Luciani); resources, G.D.S., P.G., P.M., F.A.; data curation, L.M., A.d.S.; writing-original draft preparation, F.A., L.M., A.d.S.; writing-review and editing, L.G. and G.M.; visualization, A.A., G.D.S.; supervision, F.A. and E.C. The working group members facilitate the study. All authors have read and agreed to the published version of the manuscript.

Funding: This research received no external funding. G.C.M. was supported by funds from the EU project AIM1829805-3.

Institutional Review Board Statement: The study was conducted according to the guidelines of the Declaration of Helsinki and approved by the Local Ethics Committee (approval code: 2020.68).

Informed Consent Statement: Informed consent was obtained from all subjects involved in the study.

Data Availability Statement: Dataset is available on request.

Conflicts of Interest: The authors declare no conflict of interest.

\section{Appendix A}

G\&P Working Group enclosed: Davida Mirra (Department of Experimental Medicine L. Donatelli, Section of Pharmacology, School of Medicine, University of Campania Luigi Vanvitelli, Naples, Italy), Federica Pasceri and Ilenia Talotta (Department of Microbiology and Virology, Pugliese Ciaccio Hospital, Catanzaro, Italy.) Francesco Quintieri (Department of Infectious Disease, Pugliese Ciaccio Hospital, Catanzaro, Italy), Michela Carollo (Operative Unit of Clinical Chemistry Laboratory, Pugliese Ciaccio Hospital, Catanzaro, Italy), Antonio Siniscalchi (Department of Neurology, Annunziata Hospital, Cosenza, Italy), Eugenio Garofalo (Department of Medical and Surgical Science, Operative Unit of Anesthesiology and Reanimation School of Medicine, University of Catanzaro, Italy), Stefania Zampogna (Department of Children Diseases, Pugliese Ciaccio Hospital, Catanzaro, Italy), Girolamo Pelaia (Department of Health Science, School of Medicine, University of Catanzaro, Operative Unit of Respiratory Disease, Mater Domini University Hospital, Catanzaro, Italy), Alessia Fazio and Roberto Cannataro (Department of Pharmacy, Health and Nutritional Sciences, Department of Excellence 2018-2022, University of Calabria, Cosenza, Italy). 


\section{References}

1. Martín Giménez, V.M.; Inserra, F.; Tajer, C.D.; Mariani, J.; Ferder, L.; Reiter, R.J.; Manucha, W. Lungs as target of COVID-19 infection: Protective common molecular mechanisms of vitamin D and melatonin as a new potential synergistic treatment. Life Sci. 2020, 254, 117-808. [CrossRef]

2. Gallelli, L. Escin: A review of its anti-edematous, anti-inflammatory, and venotonic properties. Drug Des. Dev. Ther. 2019, 13, 3425. [CrossRef]

3. Sanders, J.M.; Monogue, M.L.; Jodlowski, T.Z.; Cutrell, J.B. Pharmacologic treatments for Coronavirus disease 2019 (COVID-19): A Review. JAMA 2020, 323, 1824-1836. [CrossRef]

4. Quesada-Gomez, J.M.; Entrenas-Castillo, M.; Bouillon, R. Vitamin D receptor stimulation to reduce acute respiratory distress syndrome (ARDS) in patients with coronavirus SARS-CoV-2 infections: Revised Ms SBMB 2020_166. J. Steroid Biochem. Mol. Biol. 2020, 202, 105719. [CrossRef] [PubMed]

5. Fu, Y.; Cheng, Y.; Wu, Y. Understanding SARS-CoV-2-mediated inflammatory responses: From mechanisms to potential therapeutic tools. Virol. Sin. 2020, 35, 266-271. [CrossRef]

6. Bikle, D.D. Vitamin D metabolism, mechanism of action, and clinical applications. Chem. Biol. 2014, 21, 319-329. [CrossRef] [PubMed]

7. Perri, M.; Pingitore, A.; Cione, E.; Vilardi, E.; Perrone, V.; Genchi, G. Proliferative and anti-proliferative effects of retinoic acid at doses similar to endogenous levels in Leydig MLTC-1/R2C/TM-3 cells. Biochim. Biophys. Acta 2010, 1800, 993-1001. [CrossRef]

8. Buitrago, C.; Boland, R. Caveolae and caveolin-1 are implicated in 1alpha,25(OH)2-vitamin D3-dependent modulation of Src, MAPK cascades and VDR localization in skeletal muscle cells. J. Steroid Biochem. Mol. Biol. 2010, 121, 169-175. [CrossRef]

9. Iolascon, G.; Mauro, G.L.; Fiore, P.; Cisari, C.; Benedetti, M.G.; Panella, L.; de Sire, A.; Calafiore, D.; Moretti, A.; Gimigliano, F. Can vitamin D deficiency influence muscle performance in postmenopausal women? A multicenter retrospective study. Eur. J. Phys. Rehabil. Med. 2018, 54, 676-682. [CrossRef] [PubMed]

10. Umar, M.; Sastry, K.S.; Chouchane, A.I. Role of Vitamin D beyond the skeletal function: A Review of the molecular and clinical studies. Int. J. Mol. Sci. 2018, 19, 1618. [CrossRef]

11. Gimigliano, F.; Moretti, A.; de Sire, A.; Calafiore, D.; Iolascon, G. The combination of vitamin D deficiency and overweight affects muscle mass and function in older post-menopausal women. Aging Clin. Exp. Res. 2018, 30, 625-631. [CrossRef]

12. Ma, H.; Zhou, T.; Heianza, Y.; Qi, L. Habitual use of vitamin D supplements and risk of coronavirus disease 2019 (COVID-19) infection: A prospective study in UK Biobank. Am. J. Clin. Nutr. 2021, 113, 1275-1281. [CrossRef]

13. Hewison, M. Vitamin D and the immune system: New perspectives on an old theme. Rheum. Dis. Clin. N. Am. 2012, 38, 125-139. [CrossRef] [PubMed]

14. Bui, L.; Zhu, Z.; Hawkins, S.; Cortez-Resendiz, A.; Bellon, A. Vitamin D regulation of the immune system and its implications for COVID-19: A mini review. SAGE Open Med. 2021, 9, 20503121211014073. [CrossRef]

15. Liu, B.; Li, M.; Zhou, Z.; Guan, X.; Xiang, Y. Can we use interleukin-6 (IL-6) blockade for coronavirus disease 2019 (COVID-19)induced cytokine release syndrome (CRS)? J. Autoimmun. 2020, 111, 102452. [CrossRef]

16. Iorio, G.C.; Ammendolia, A.; Marotta, N.; Ricardi, U.; de Sire, A. A bond between rheumatic diseases and cancer in the elderly: The interleukin-6 pathway. Int. J. Rheum Dis. 2021, 24, 1317-1320. [CrossRef] [PubMed]

17. White, J.H. Vitamin D Signaling, Infectious Diseases, and Regulation of Innate Immunity. Infect. Immun. 2008, 76, $3837-3843$. [CrossRef]

18. Holick, M.F. High prevalence of vitamin D inadequacy and implications for health. Mayo Clin. Proc. Marzo 2006, 81, 353-373. [CrossRef] [PubMed]

19. Cannell, J.J.; Vieth, R.; Umhau, J.C.; Holick, M.F.; Grant, W.B.; Madronich, S.; Garland, C.F.; Giovannucci, E. Epidemic influenza and vitamin D. Epidemiol. Infect. 2006, 134, 1129-1140. [CrossRef]

20. Ginde, A.A.; Mansbach, J.M.; Camargo, C.A. Association between serum 25-Hydroxyvitamin D level and upper respiratory tract infection in the third national health and nutrition examination survey. Arch. Intern. Med. 2009, 169, 384-390. [CrossRef] [PubMed]

21. Lu, D.; Zhang, J.; Ma, C.; Yue, Y.; Zou, Z.; Yu, C.; Yin, F. Link between community-acquired pneumonia and vitamin D levels in older patients. J. Gerontol. Geriatr. 2018, 51, 435-439. [CrossRef]

22. D'Avolio, A.; Avataneo, V.; Manca, A.; Cusato, J.; De Nicolò, A.; Lucchini, R.; Keller, F.; Cantù, M. 25-Hydroxyvitamin D concentrations are lower in patients with positive PCR for SARS-CoV-2. Nutrients 2020, 12, 1359. [CrossRef]

23. Gallelli, L.; Michniewicz, A.; Cione, E.; Squillace, A.; Colosimo, M.; Pelaia, C.; Fazio, A.; Zampogna, S.; Peltrone, F.; Iannacchero, R.; et al. 25-Hydroxy vitamin D detection using different analytic methods in patients with migraine. J. Clin. Med. 2019, 8, 895. [CrossRef]

24. Torkildsen, Ø.; Knappskog, P.M.; Nyland, H.I.; Myhr, K.-M. Vitamin D-dependent rickets as a possible risk factor for multiple sclerosis. Arch. Neurol. 2008, 65, 809-811. [CrossRef]

25. Afzal, S.; Bojesen, S.E.; Nordestgaard, B.G. Low 25-Hydroxyvitamin D and risk of type 2 diabetes: A prospective cohort study and metaanalysis. Clin. Chem. 2013, 59, 381-391. [CrossRef] [PubMed]

26. Lee, J.E.; Li, H.; Chan, A.T.; Hollis, B.W.; Lee, I.-M.; Stampfer, M.J.; Wu, K.; Giovannucci, E.; Ma, J. Circulating levels of vitamin D and colon and rectal cancer: The physicians' health study and meta-analysis of prospective studies. Cancer Prev. Res. 2011, 4, 735-743. [CrossRef] 
27. Keller, A.; Varela Vazquez, C.; Dangol, R.; Damm, P.; Heitmann, B.L.; Händel, M.N. The role of vitamin D in the development of diabetes post gestational diabetes mellitus: A systematic literature review. Nutrients 2020, 12, 1733. [CrossRef]

28. Osorio Landa, H.K.; Pérez Díaz, I.; Laguna Bárcenas, S.D.C.; López Navarro, J.M.; Abella Roa, M.F.; Corral Orozco, M.; MancillaOrtega, J.P.; Martínez-Duarte, D.A.; Morales-Montalvo, S.I.; Múzquiz-Aguirre, S.; et al. Association of serum vitamin D levels with chronic disease and mortality. Nutr. Hosp. 2020, 37, 335-342.

29. Siniscalchi, A.; Lochner, P.; Anticoli, S.; Chirchiglia, D.; De Sarro, G.; Gallelli, L. What is the current role for vitamin D and the risk of stroke? Curr. Neurovasc. Res. 2019, 16, 178-183. [CrossRef] [PubMed]

30. Chamekh, M.; Casimir, G. Editorial: Sexual dimorphism of the immune inflammatory response in infectious and non-infectious diseases. Front. Immunol. 2019, 10, 107. [CrossRef] [PubMed]

31. Jin J-M, B.P.; He, W.; Wu, F.; Liu, X.-F.; Han, D.-M.; Lui, S.; Yang, J.-K. Gender differences in patients with COVID-19: Focus on severity and mortality. Front. Public Health 2020, 8, 152. [CrossRef]

32. Koenig, A.; Buskiewicz, I.; Huber, S.A. Age-Associated changes in estrogen receptor ratios correlate with increased female susceptibility to Coxsackievirus B3-Induced myocarditis. Front. Immunol. 2017, 16, 8:1585. [CrossRef]

33. Mauvais-Jarvis, F.; Klein, S.L.; Levin, E.R. Estradiol, progesterone, immunomodulation, and COVID-19 outcomes. Endocrinology 2020, 161, bqaa127. [CrossRef]

34. Yan, X.; Zhang, N.; Cheng, S.; Wang, Z.; Qin, Y. Gender differences in vitamin D status in China. Med. Sci. Monit. Int. Med. J. Exp. Clin. Res. 2019, 25, 7094-7099. [CrossRef] [PubMed]

35. Manion, M.; Hullsiek, K.H.; Wilson, E.M.P.; Rhame, F.; Kojic, E.; Gibson, D.; Hammer, J.; Patel, P.; Brooks, J.T.; Baker, J.V.; et al. Vitamin D deficiency is associated with IL-6 levels and monocyte activation in HIV-infected persons. PLoS ONE 2017, 12, e0175517. [CrossRef]

36. Liu, Q.; Zhou, Y.; Yang, Z. The cytokine storm of severe influenza and development of immunomodulatory therapy. Cell Mol. Immunol. 2016, 13, 3-10. [CrossRef] [PubMed]

37. Labudzynskyi, D.; Shymanskyy, I.; Veliky, M. Role of vitamin D3 in regulation of interleukin-6 and osteopontin expression in liver of diabetic mice. Eur. Rev. Med. Pharmacol. Sci. 2016, 20, 2916-2919. [PubMed]

38. Mehta, P.; McAuley, D.F.; Brown, M.; Sanchez, E.; Tattersall, R.S.; Manson, J.J. HLH across speciality collaboration, UK. COVID-19: Consider cytokine storm syndromes and immunosuppression. Lancet 2020, 395, 1033-1034. [CrossRef]

39. Negrini, F.; de Sire, A.; Andrenelli, E.; Lazzarini, S.G.; Patrini, M.; Ceravolo, M.G. International multiprofessional steering committee of cochrane rehabilitation REH-COVER action. rehabilitation and COVID-19: The cochrane rehabilitation 2020 rapid living systematic review. update as of July 31st, 2020. Eur. J. Phys. Rehabil. Med. 2020, 56, 652-657. [CrossRef]

40. Ferraro, F.; Calafiore, D.; Dambruoso, F.; Guidarini, S.; de Sire, A. COVID-19 related fatigue: Which role for rehabilitation in post-COVID-19 patients? A case series. J. Med. Virol. 2021, 93, 1896-1899. [CrossRef]

41. Griffin, G.; Hewison, M.; Hopkin, J.; Kenny, R.; Quinton, R.; Rhodes, J.; Subramanian, S.; Thickett, D. Vitamin D and COVID-19: Evidence and recommendations for supplementation. R. Soc. Open Sci. 2020, 7, 201912. [CrossRef] [PubMed]

42. Griffin, G.; Hewison, M.; Hopkin, J.; Kenny, R.A.; Quinton, R.; Rhodes, J.; Subramanian, S.; Thickett, D. Preventing vitamin D deficiency during the COVID-19 pandemic: UK definitions of vitamin D sufficiency and recommended supplement dose are set too low. Clin. Med. 2021, 21, e48-e51. [CrossRef] [PubMed] 